UNIVERSITY OF CHITRAL JOURNAL OF LINGUISTICS AND LITERATURE

VOL. 4 | ISSUE II | JULY - DEC | 2020

ISSN (E): 2663-1512, ISSN (P): 2617-3611

\title{
How satisfied are the English Major Students with their Foundation English Courses: An Appraisal
}

\author{
Dr. Usha Sadasivan \\ Head, Department of English, Meenakshi College for Women, Chennai, India \\ ushasadasivan14@gmail.com \\ Dr. S. Vijayalakshmi \\ Associate Professor of English, School of Social Sciences and Languages, Vellore, India \\ svijayalakshmi@vit.ac.in \\ Dr. Bhuvaneswari Balachander \\ Assistant Professor, Department of Electronics and Communication Engineering Saveetha \\ School of Engineering, Chennai, India \\ bhuvaneswari@saveetha.com
}

\begin{abstract}
The purpose of this study was to investigate and evaluate the level of satisfaction of the English Major students with their Foundation English course. To this end, a questionnaire was administered to students currently pursuing the course, as well as students who had completed the course. The motive was to compare the results of the two sets of responses to see if both sets of students felt the same regarding the foundation English curriculum. The questionnaire was selfadministered, through Google forms. The study threw light on the responsibilities of educational institutions in understanding that higher education is a service industry. It also highlighted the need for educational institutions to realize that they need to satisfy needs and the expectations of students, parents and employers. These three are the main stakeholders in the education industry today. Syllabus framers too have to accept that changes are imminent and make more than cosmetic changes to accommodate changes in the world outside. Students should be roped into the curriculum framing committees as they know what they need and what is not being delivered to them .Giving importance to aspirations of students is unavoidable. It is hoped that this study would throw light on the expectations of students so that necessary changes may be made in the curriculum and thereby bring about the desired learning outcomes.
\end{abstract}

Key words: student satisfaction- foundation courses- curriculum framing 


\section{Introduction}

Colleges, especially those that come under the autonomous stream, have the freedom to choose their own texts and learning material. A lot of scope is provided for colleges to select texts which lead to desired learning outcomes. These colleges can use their freedom to focus on providing skills such as curiosity to learn, courage to face new situations, passion and interest to realize their potential, and to be adept at communication. Attributes which are desired by the employer or higher education selection panel should be the learning outcome of any undergraduate program. The curriculum designing team should take into account how they can maximize the preparation of students for future requirements. The onus of preparing students for the world outside rests on the curriculum planners to make them industry- ready when they graduate.

\section{Methodology}

\section{Research Design}

The present study was to test if the existing Foundation Course English syllabus satisfies the needs of the students pursuing their major in English literature. The design was to administer a questionnaire to students currently pursuing the course, as well as students who had completed the course.

\section{Participants}

A survey of students currently pursuing graduate from the undergraduate course in English Literature, from a city college was undertaken. . The questionnaire was administered online to around 200 respondents. The questionnaire was self-administered and was distributed via Google forms. The total number of respondents who returned the questionnaire was 112 currently pursuing the course and 50 who had completed the course. The questions used were of the Likert type, to test the attitudes of the respondents.

\section{Instrumentation}

The methodology to be adopted is the comparative analysis type to compare the responses of those undergoing the course, with responses of recent graduates of the undergraduate course in B A English Literature. The aim of the analysis was to see if the two sets of respondents showed similarities in their responses, in order to check how satisfied they were with the Foundation 
programme, that they had undertaken, as part of their undergraduate course. This study gains relevance especially against the backdrop of getting employment after graduation.

\section{Hypothesis}

- Foundation courses in English at Undergraduate level provide necessary job skills.

- Foundation English courses are interesting for students.

- English Major Students are satisfied with the content of the Foundation English courses.

\section{Review of literature}

Potari and Jaworski (2002) state that teachers engage in different domains of activity as they teach, one of them being sensitivity to student needs. This sensitivity to students can also operate in different domains. Teachers can reveal sensitivity through questioning and seeking conceptual explanations.

Education today is not merely board method of imparting knowledge and filling the heads of students with tried and tested formulae. Educational institutions have begun to clearly understand and increasingly recognize that higher education is a 'service industry' and that greater emphasis has to be given to satisfying the expectations of their customers, i.e. students (DeShields, Jr. et al., 2005).

Skills that could be introduced into the existing curriculum can be taught by tweaking the existing lesson material to highlight industry-specific skills. Skills which can be explored and which are not too difficult to manage with existing teacher resources and which incidentally have a focus on employability are listed below:

- Communication skills

- Journalistic skills

- Analytical Skills

- Verbal ability skills

- Blogging skills

- $\quad$ Basic Computer skills 


\section{- Interview skills \\ - $\quad$ Speech writing \\ - $\quad$ Project writing \\ - Performance based assignments \\ - Projects to promote team work \\ - Work place settings simulations \\ - Creative writing workshops}

The difficulties that could arise in the implementation of far-reaching changes is that, teachers especially those that are new to the professions may find it difficult to integrate skill development into their regular teaching. They need to be given fewer classes and more time to adjust to the new requirements. Another difficulty is, identifying students' strengths, interests and talents and integrating them into daily teaching practice.

Sometimes matching the contexts of the job market and student strengths is difficult, because it involves a better understanding of assets and resources within the community as well as other socio-cultural dimensions.

Curriculum planners have to assess the needs of students and re-invent their methods by finding a new one or rework an existing one on a continual basis.

What is required is the identification of the needs of the students, which is what the questionnaire aims to do. Once the needs of students are identified, they have to be matched with the needs of the employers when they seek employment. The curriculum has to therefore offer a via channel which links the two and makes them more industry-ready.

The existing curriculum of the Foundation Course in English typically has a literature component consisting of prose, poetry, short stories, short fiction as well as longer fiction novellas, novels, autobiography, and plays. Texts are chosen from typically representative writers of the age or genre. Together with these texts they are given training in writing skills and grammar and composition to improve their language skills.

The syllabus reformers typically juggle the literature, grammar and composition items without any serious changes actually being made because the existing syllabus is tried and tested, 
having been successfully implemented for decades. Not much serious changes are made to take into account the changing needs of the world outside which has seen drastic changes especially in the past few years.

Most of the syllabus framers are unwilling to accept that changes are imminent and make only cosmetic changes. Students should also be roped into the syllabus framing committees. They have to identify what results are to be reached, then choose texts which bring about that end. The Foundation course in English has an enviable position as one of a kind. No other course is offered to all students across all disciplines. This makes the responsibility of all those handling the course, all the more greater. A whole generation of students is entrusted in the care of the teachers and syllabus framers of this course and they have to shake off their cloak of comfort, and make complete and thorough changes. It will be difficult at first to completely overhaul the syllabus, but once set in motion, the next time around it will be easier to handle. The world outside requires from the fresh graduates, a great degree of understanding and an enormous amount of maturity, and industry readiness that seems almost impossible. Recruiters expect the educational institutions to provide work skills training and send out fully equipped students who are ready to be lapped up by the employers. When this is the requirement of the world, it becomes the imperative duty of the educational institutions to rise up to the challenge and offer what is needed.

The questionnaire - The items in the questionnaire utilized the Likert scale with predictor variables such as strongly disagree, disagree, agree, strongly agree; and extremely good, good, moderate, poor .

Samples for the survey- The samples were a representative sample of those undergoing the English Major course of study and were taken to be representative of the opinion of the entire student population undergoing the same course of study. It represents the opinions of a niche set of students, but can still be considered a sample of typical opinions of students of the same age and demographics. 162 students returned the questionnaire, which was self- administered via Google forms, of which 112 were students currently pursuing the course and 50 who had recently completed the course.

\section{Analysis of data}


How did you feel about your English classes in college?

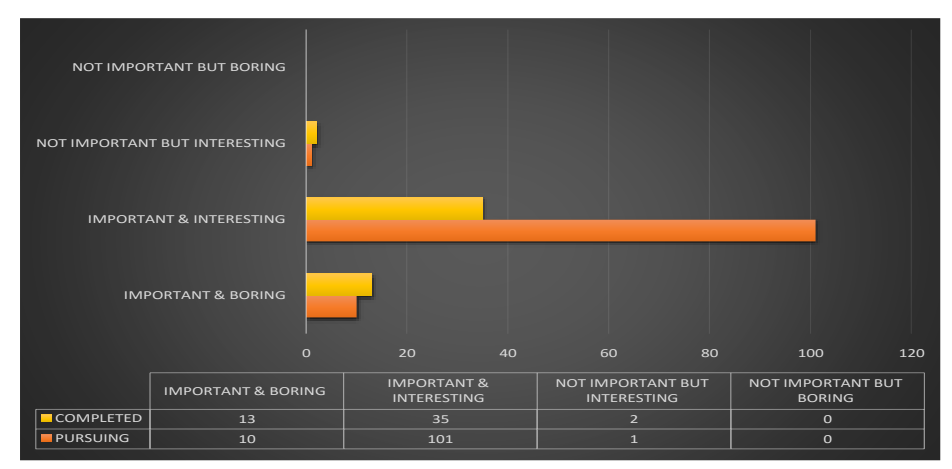

Figure 1

Of those pursuing the course, 101/112 found it important and interesting, 10/112 found it important and boring only one responded that it was not important but interesting. From this we understand that $111 / 112$, that is $99 \%$ found the existing syllabus important. Not even one respondent found it unimportant,

The responses of the students who had recently completed 13/50 found it important and boring while 35/50 found it important and interesting and only 2/50/found it as not important but interesting. From those responses we can infer that $96 \%$ found it important with $26 \%$ finding it boring and $70 \%$ finding it interesting. Not even one respondent found it unimportant This question shows beyond doubt that the students who had completed the course as well as those who are undergoing the course find the syllabus interesting.

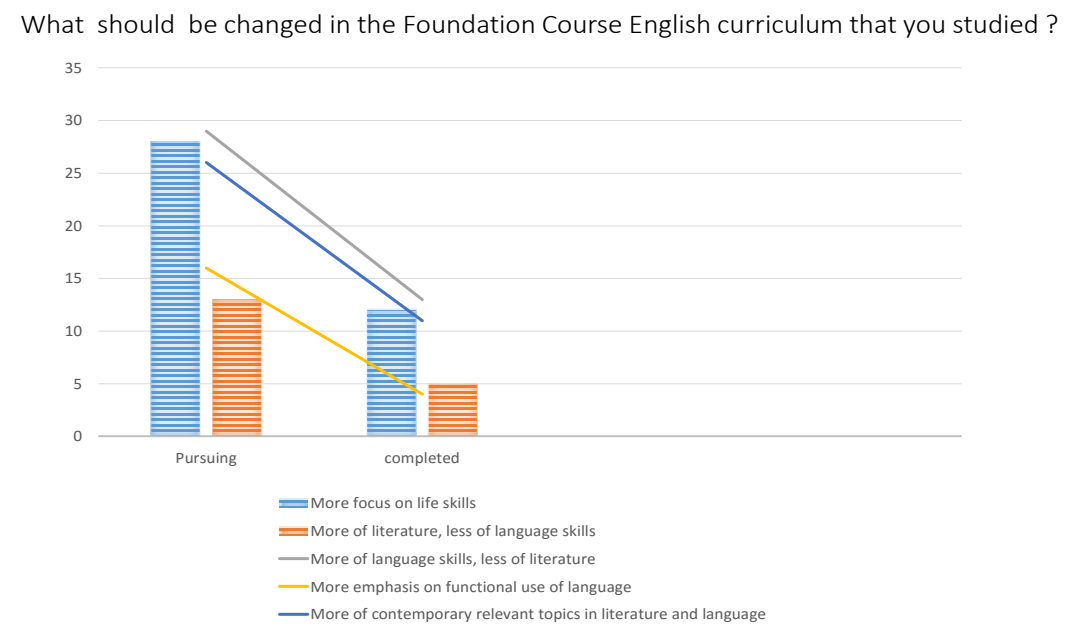




\section{Figure 2}

\begin{tabular}{|l|l|l|l|l|l|}
\hline Pursuing & 28 & 13 & 29 & 16 & 26 \\
\hline completed & 12 & 5 & 13 & 9 & 11 \\
\hline
\end{tabular}

To the question as to what should be changed in the existing syllabus, 28/112 felt that more focus should be on life skills while $12 / 50$ of those completed felt the same.

While 13/112 of those pursuing felt that there should be more literature and less of language skills $5 / 50$ of those completed felt the same.

29/112 felt there should be more of language skills and less of literature while 13/50 of those who had completed the course felt the same regarding language skills. .

$16 / 112$ of those that were pursuing the course felt that more emphasis should be on functional use of language while $9 / 50$ of those completed felt the same.

$26 / 112$ of the respondents from those pursuing the course felt that there should be more contemporary relevant topics in literature and language while 11/50 of those that had completed felt the same.

Do you think writing skills can be improved by reading literary classics?

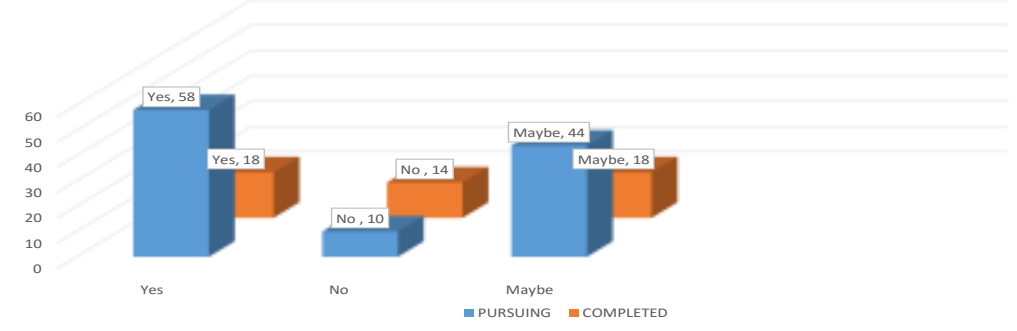

Figure 3

To the question if writing skills can be improved by reading literary classics. $51.9 \%$ said yes and 39\% said maybe .Of those that had completed 36\% said yes and the same percentage said maybe. Only $9 \%$ of those pursuing said writing skills could not be improved by reading literary classics, while $28 \%$ of those that had completed said no, which was three times more than the 
UNIVERSITY OF CHITRAL JOURNAL OF LINGUISTICS AND LITERATURE

VOL. 4 | ISSUE II | JULY - DEC | 2020

ISSN (E): 2663-1512, ISSN (P): 2617-3611

responses of those who are currently pursuing the course.
Do you feel the curriculum should focus more on some of the
employability enhancing skills?

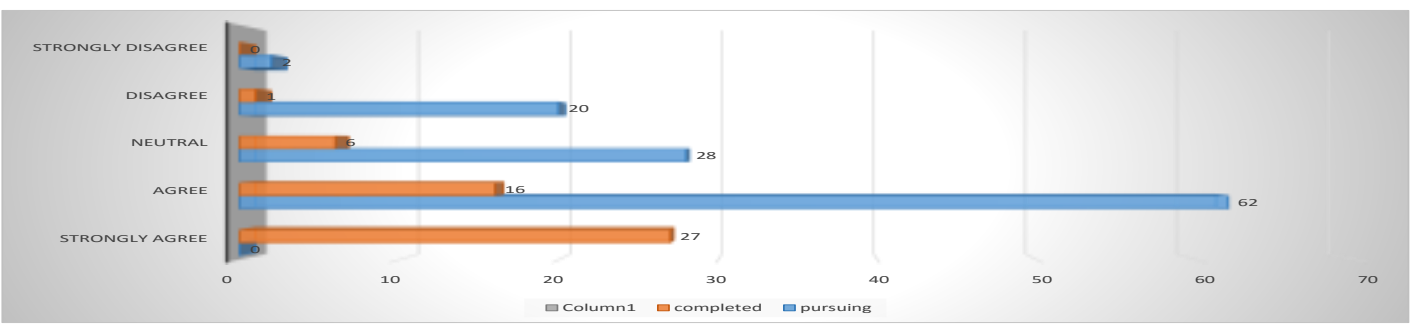

Figure 4

\begin{tabular}{|l|r|l|}
\hline & pursuing & completed \\
\hline Strongly agree & 0 & 27 \\
\hline Agree & 62 & 16 \\
\hline Neutral & 28 & 6 \\
\hline Disagree & 20 & 1 \\
\hline strongly disagree & 2 & 0 \\
\hline
\end{tabular}

To the question if the curriculum of the foundation course should focus on some of the employability enhancing skills the responses show that $55 \%$ of those pursuing the course wanted employment skills to be incorporated into the curriculum. $83 \%$ of those who had completed the course held the opinion that necessary employment enhancement skills need to be incorporated into the curriculum and this is especially significant as they are now in the world outside seeking employment and feel the need more than those currently pursuing the course.

Were you satisfied with the methodology adopted in the implementation of the curriculum?

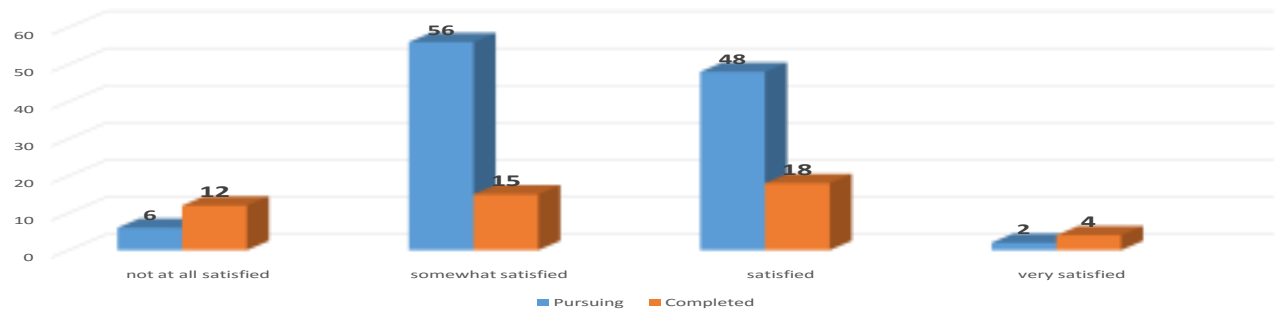

Figure 5 
The responses to the question about whether they satisfied with the methodology employed in the implementation of the curriculum we may infer from the data received that $54 \%$ of those who had completed and $55.4 \%$ of those pursuing the course were not satisfied with the methodology adopted.

Are communication skills developed by your foundation English courses in college ?

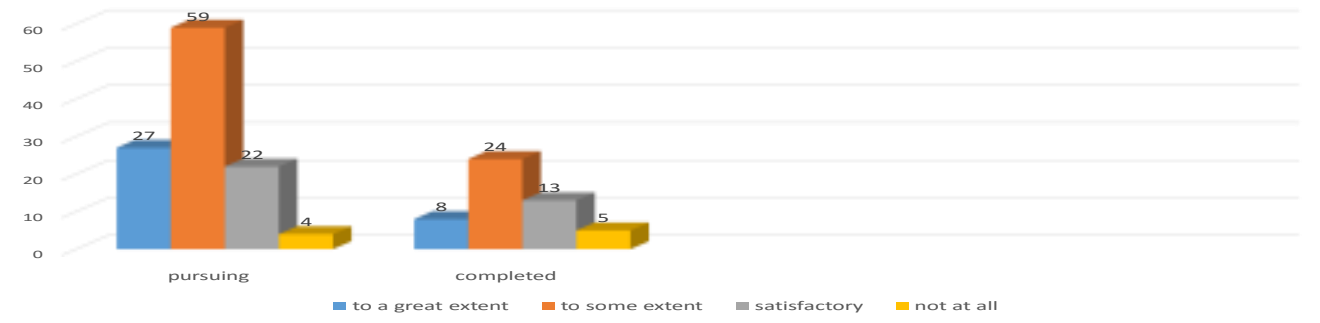

Figure 6

\begin{tabular}{|c|c|c|c|c|}
\hline & $\begin{array}{l}\text { to a great } \\
\text { extent }\end{array}$ & $\begin{array}{ll}\text { to some } \\
\text { extent }\end{array}$ & $\begin{array}{l}\text { satis } \\
\text { factory }\end{array}$ & no \\
\hline $\begin{array}{ll} & \text { purs } \\
\text { uing } & \end{array}$ & 27 & 59 & 22 & 4 \\
\hline pleted $^{\text {com }}$ & 8 & 24 & 13 & 5 \\
\hline
\end{tabular}

To the question whether communication skills were developed by their foundation courses in college $24 \%$ of those that were currently pursuing the course said to a great extent, $52.67 \%$ to some extent and $19.6 \%$ found it satisfactory. Only $3.57 \%$ were of the opinion that these skills are not developed.

Of the responses from those that had completed the course, $16 \%$ felt that it developed communication skills to a great extent, $48 \%$ to some extent, $26 \%$ found it satisfactory, while $10 \%$ found that it did not develop communication skills at all. 
The responses of those who completed the course appear to be more relevant as they are in the world outside where the skills they had mastered in college will be of use while seeking employment or in going up in the careers.

\section{Summary of findings}

The analysis of the responses threw up some interesting observations. There were similar thinking among the students who had recently completed the course and those currently pursuing the course in that both groups of students found the foundation course interesting as well as important which proves beyond doubt that the course as such was not without its merits, only changes had to be brought in.

The responses to the question on whether they found the foundation course important and interesting, 99\% of the respondents who are pursuing the course found the existing syllabus important. Similarly from the responses of the students who had recently completed we can infer that $96 \%$ found it important . Not even one respondent found it unimportant .This question states beyond doubt that the students who had completed the course as well as those who are undergoing the course find the Foundation syllabus important and interesting. What they needed were certain skill enhancement changes to be incorporated

To the question regarding what should be changed in the existing syllabus, we find a similar trend in the answers of both those who are currently pursuing and those that had recently completed the course. $25 \%$ of those pursuing felt that more focus should be on life skills while $24 \%$ of those completed felt the same.

$25.89 \%$ of those pursuing felt there should be more language skills and less literature while $26 \%$ of those who had completed the course felt the same regarding language skills. .23.2 $\%$ of the respondents from those pursuing the course felt that there should be more contemporary relevant topics in literature and language, while $22 \%$ of those that had completed felt the same.

To the question of whether writing skills could be improved by reading literary classics, $9 \%$ of those pursuing said it did not. $28 \%$ of those that had completed said no, which shows that these students having stepped out of college, found the literary classics that were offered as part of the Foundation course, was not helping their writing in real-life situation. 
Again to another question, we find that most of the students pursuing the course thought that the curriculum-improved communication skills, $48 \%$ of those that had completed the course felt the same while $10 \%$ found that it did not develop communication skills at all. This $10 \%$ is of relevance because these are the students who have gone out into the employment world and it is here that they will be needing the skills they should have been taught in college as part of their foundation courses.

\section{Verification of Hypothesis}

Hypothesis 1-Foundation courses in English at the Undergraduate level provide necessary job skills. Not proved as $83 \%$ wanted more of employment enhancement skills to be incorporated into the curriculum.

Hypothesis 2- Foundation English courses are interesting for students.Stands proved- as almost $99 \%$ of respondents said they found it interesting

Hypothesis 3- English Major Students are satisfied with the content of the Foundation English courses not proved conclusively as both sets of respondents wanted changes to be brought in the curriculum.

\section{Recommendations}

The curriculum planners in the future need to keep in mind that employment opportunities as well as interest of students need to be kept in mind while framing the curriculum.

Needs of students vary with situations and over time and syllabi have to be continually upgraded to suit existing needs.

Students need to be actively involved in the curriculum planning.

\section{Conclusion}

The education planners should come out of obsolete ways of thinking and formulate new curricula taking into account the information technology revolution, quality of education, stakeholder expectations.

\section{Bibliography}

Bench- marking student satisfaction in higher education based on the ECSI methodology, Proceedings of the Conference on TQM for Higher Education Institutions (Verona, 
UNIVERSITY OF CHITRAL JOURNAL OF LINGUISTICS AND LITERATURE

VOL. 4 | ISSUE II | JULY - DEC | 2020

ISSN (E): 2663-1512, ISSN (P): 2617-3611

$\begin{array}{lllll}\text { University of } & \text { Verona). } & \text { García-Aracil, } & \text { (2008) }\end{array}$

https://doi.org/10.1371/journal.pone.0189576

College student satisfaction: an indication of institutional vitality, N.A. S.PA. Journal, 16, pp. 19-

24. Hartman, D. \& Schmidt, S. (1995) doi/abs/10.1080/00220973.1978.11071708

Defining customer satisfaction, Academy of Marketing Science Review, 00(01), pp. 1-34. Hallenbeck, R. (1978) https://doi.org/10.1080/1331677X.2018.1484786

Delivering on the modernization agenda for universities: education, research and innovation (Brussels, COM(2006) 208 final). Deshields, jr., O, Kara, A. \& Kaynak, E. (2005) $10.2766 / 17689$

European graduates' level of satisfaction with higher education, Higher Education (Springer) . Giese, J. \& Cote, J. (2000) 10.1007/s10734-008-9121-9

Guaranteed student success: General education and occupational programs. Community College Review, 19(1), 14-23. Pascarella, E., \&Terenzini, P. T. (2005) https://doi.org/10.1177/009155219101900104

High-impact educational practices: What they are, who has access to them, and why they matter. Washington, D.C.: Association of American Colleges and Universities. Lo, C. C. (2010).

Key factors influencing student satisfaction related to recruitment and retention, Journal of Marketing for Higher Education, 10, pp. 1-11. Elliott, K. \& Shin, D. (2002) 10.1300/J050v10n04_01

Kumar, A., \& Syed, H. (2021). Facebook as a Language Learning Environment: A Descriptive Study on ESL Learners' Perceptions. University Of Chitral Journal Of Linguistics \& Literature, 2(I), 64-76. doi:10.33195/j1l.v2iI.165

Seven principles for good practice in under-graduate education. Bulletin, 39(7), 3-7. Chickering, A. W., \&Ehrmann, S. C. (1996). https://doi.org/10.1016/0307-4412(89)90094-0 
Student satisfaction: an alternative approach to assessing this important concept, Journal of Higher Education Policy and Management, 24, pp. 197-210. Eskildsen, J., Martensen, A., Gronholdt, L. \& Kristensen, K. (1999) https://doi.org/10.1080/1360080022000013518

Qadar, Abdul. " British Council's English for Academic Purposes: A Critical Analysis of the Coursebook Taught at Pakistani Universities." University of Chitral Journal of Linguistics \& Literature [Online], 3.I (2019): 20-28. Web. 25 Mar. 2021

The application of a model of turnover in work organizations to the student attrition process. The Review of Higher Education, 6, pp. 129-148. Beltyukova, S. \& Fox, C. M. (2002) 10.1353/rhe.1983.0026

The effect of teaching general education courses on deep approaches to learning: How disciplinary context matters. Research in Higher Education, 51, 248-65.Nelson Laird, T. F., NiskodéDossett, A. S., \&Kuh, G. D. (2009). https://www.jstor.org/stable/40606360

The leap vision for learning: Outcomes, practices, impact, and employers' view. Washington, D.C.: Author. Astin, A. W. (1992).

Towards a theory of student satisfaction: an explanatory study of the "Quality of Student Life", Journal of College Student Development, 36, p. 574. Benjamin, M. \& Hollings, A. (1997) 10.1080/08841241.2017.1311980

What really matters in college: How students view and value liberal education. Liberal Education, 91(3/4), 36-43. Kegan, R. (1994). https://www.aacu.org/publicationsresearch/periodicals/what-really-matters-college-how-students-view-and-value-liberal.

What really matters in general education: Provocative findings from a national study of student outcomes. Perspectives, 22(1), 23-46. Bourke, B., Bray, N. J., \& Horton, C. C. (2009).

\begin{tabular}{l|l}
\hline CC) 12020 by the author. Licensee University of Chitral, \\
Jy
\end{tabular} \begin{tabular}{l}
$\begin{array}{l}\text { Oournal of Linguistics \& Literature, Pakistan. This article is an } \\
\text { open access article distributed under the terms and conditions of } \\
\text { the Creative Commons Attribution (CC BY) } \\
\text { (http://creativecommons.org/licenses/by/4.0/). }\end{array}$ \\
\hline
\end{tabular}

